\title{
The map, the group and language ideology
}

\author{
Sue Wright* \\ CEISR, University of Portsmouth, Portsmouth, UK \\ (Received 27 September 2014; Accepted 8 May 2014)
}

\begin{abstract}
This article chronicles the history of mapmaking, showing how the way maps develop is in tandem with the development of patterns of group identity. The central question concerns our ways of conceptualising the physical world and whether these feed into language ideology, that set of beliefs, values and attitudes drawn from our sociopolitical environment, which directs, constrains and moulds our language behaviour. Benedict Anderson noted the parallel development of mapping, identity and language practices in nation building. My argument here is that it is also possible to see this association in the European medieval world and that there are some indicators that such co-occurrence is discernible in mapmaking, identity formation and language practices in post-national settings. As ever in the social sciences, it would be inappropriate to claim clear cause and effect. However, it is possible to demonstrate that changes in world view co-occur with changes in language behaviour. It may, therefore, be legitimate to hypothesise that the view of ourselves that maps give us and the identities we assume as part of groups thus constructed play some part in the choice of languages we willingly acquire and speak.
\end{abstract}

Keywords: language; ideology; identity; map; groups

\section{Introduction}

Human language has first and foremost an information-carrying function. Being able to express ideas in language allows human beings to remember the past, organise the present and plan the future. Language allows individuals to negotiate with each other, to cooperate and thus to live in groups. The fact that this human attribute has developed as languages rather than language has added another very important function: the use of a language variety within a group defines the parameters of the group; it includes as members all those who are speakers and excludes all those who cannot speak the language. Language thus has a role to play in the construction of political/social identity as communication takes place and social interaction cements relationships among members of the language community.

It is this aspect of the complexity of language that I want to examine in this article. What is the interplay between the identity dimension of language and its communicative function? How has it developed as human groups have moved from simple, oral, face-toface societies to multilingual empires, to the mosaic of the nation state system and most recently to the networks and relations of globalisation? I then want to study how the wider construction of identity fits with the formation of language identity and how these both interact with the communication requirements of the individual, the group and the polity.

*Email: sue.wright@port.ac.uk 
Such work must draw on the extensive political science literature on polity and identity, in particular on a number of seminal works on nationalism published in 1983 in the English-speaking world. Ernest Gellner's Nations and Nationalism, Benedict Anderson's Imagined Communities: Reflections on the Origin and Spread of Nationalism and Eric Hobsbawm's and Terence Ranger's edited book The Invention of Tradition analyse nation building and demonstrate how political groups are constructed, making clear that the cultivation of national identity is an essential part of the process of state building. These authors demonstrate how identity is fostered intentionally in the course of nation building; a great deal of our loyalty to and identification with the nation comes from conscious top-down planning. Within the sovereign state, a single national legal system, a single protected domestic market, a single citizens' army, national media and a national education system all frame the inevitable socialisation of the individual as citizen. They also show how national identity develops as an unintended additional consequence of other policies and phenomenon, such as urbanisation and industrialisation. For the purposes of this article, I want to take just one of the small jigsaw pieces that are claimed to contribute in an unpremeditated way to the construction of national identity. This is the map. In his 1991 revision of Imagined Communities, Benedict Anderson added a chapter on mapmaking in the colonial period and demonstrated how potent the drawing of boundary lines had been on the imagining of post-colonial states.

Using Anderson's insights as a starting point, I would like to explore the possible links between the imagined territory of the map, the view that such representation gives us of our place in the world and issues of social identity and language. I would be wary of claiming any simple cause-and-effect relationship. However, it would be reasonable to suggest co-occurrence and that our apprehension of space and our place within it works together with all the other agents of identity construction and develops in tandem with our language ideology. In other words, unless there are superordinate reasons not to comply, we are prepared to communicate (and to learn to communicate) with the members of "our" geographical space. What evidence is there to suggest that what a group perceives as its geographical space plays a role in the decisions it makes about language maintenance/acquisition/shift and societal bi- or multilingualism or monolingualism?

To develop this hypothesis, I examine maps of the medieval world, maps of the national period and maps of the twenty-first century. The maps here are the large-scale maps that are made for reasons other than route finding. These maps portray the world view of the elites that commissioned them and the scholars that produced them. They are not simply a scientific abstraction of reality. They resemble the maps of the colonial period, which Thongchai (quoted in Anderson 1991, 177) suggested "anticipate(d) spatial reality, not vice versa. In other words, a map was a model for, rather than a model of, what it purported to represent".

My geographical focus in this article has been Europe, for no reason other than my own competence. The argument could apply equally to other parts of the world. The pattern of the article is chronological. Looking first at the maps of the medieval period, we can see that their makers saw themselves as part of the Christian world and that the map invites its audience to a spiritual journey rather than physical transportation. In the second section, the maps of modernity provide a more accurate view of the physical world. Mercator's work on projection (1569) and Harrison's invention of the chronometer (1761) produced a geometrical grid on which territory could be positioned and marked as possession. These maps present a world view prevalent in the era of sovereign territory and the nation state. In the third section, I consider the maps taken from satellites, which 
many can now access through the new e-technologies. Such images from space present territory to us with physical features only, and there is no evident political/philosophical/ spiritual interpretation imposed on the data. However, once again, we find ourselves in a political/social environment (globalisation), which seems to be mirrored in the maps we employ (Google Earth and Bing).

\section{The world view of the medieval era}

The maps that were drawn to represent the world as medieval Europeans conceived it reveal the central importance of religion in the medieval society. The map is clearly a map of belief rather than of the physical world, an exposition of Christian thinking, rather than a guide or aid for travel. The medieval mapmaker was concerned to provide for a spiritual journey rather than an actual expedition.

This simplified diagram of the medieval European map of the world shows how the world was presented as a circle, divided into three parts (Figure 1). The largest area in the circle is Asia, and the other two areas, Europe and Africa, are of equal size. The continents are separated by waterways drawn in a schematic way, as a T within the $\mathrm{O}$ of the circle. The central position of Jerusalem and the orientation, with east at the top of the map and paradise at the most easterly point, reveals the world view of the mapmakers and the pre-eminence that spiritual matters had for them.

The earliest example of the $\mathrm{T}$ and $\mathrm{O}$ map is attributed to St Isidore, Bishop of Seville in the seventh century. The map appeared in Etymologiarum sive Originum, a 20-volume encyclopaedia in which the author drew together knowledge from classical writers, as well as the teachings of the church (Figure 2). The three continents are labelled with the names of Noah's sons Shem, Japhet and Ham, evoking the story of the Ark from the Old Testament to explain racial origins. The $\mathrm{T}$ was obvious to contemporary Christians as a symbol of Christianity spanning the known world (Lanman 1981).

The tripartite division of the world into Asia, Africa and Europe, surrounded by ocean, was probably first conceived by the Greeks as early as the fifth century BC. The

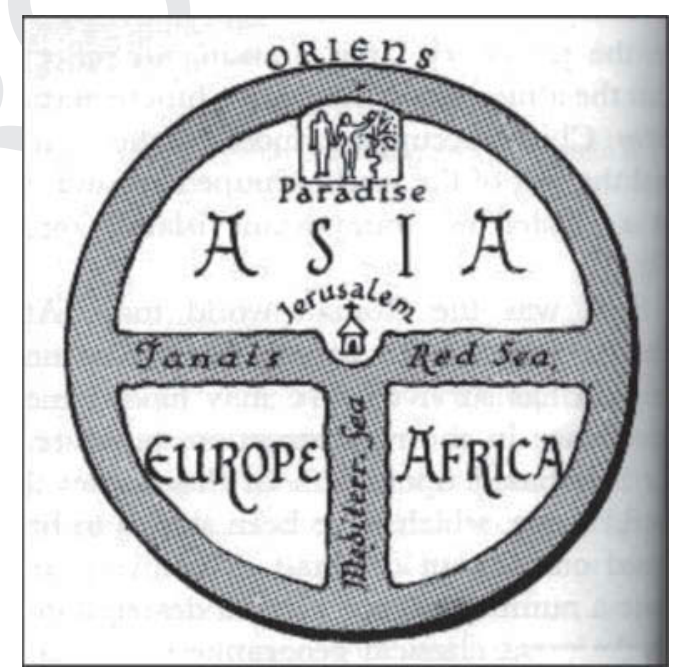

Figure 1. Diagram of $\mathrm{T}$ and $\mathrm{O}$ map. Source: http://www.henry-davis.com/MAPS/EMwebpages/ 205mono.html 


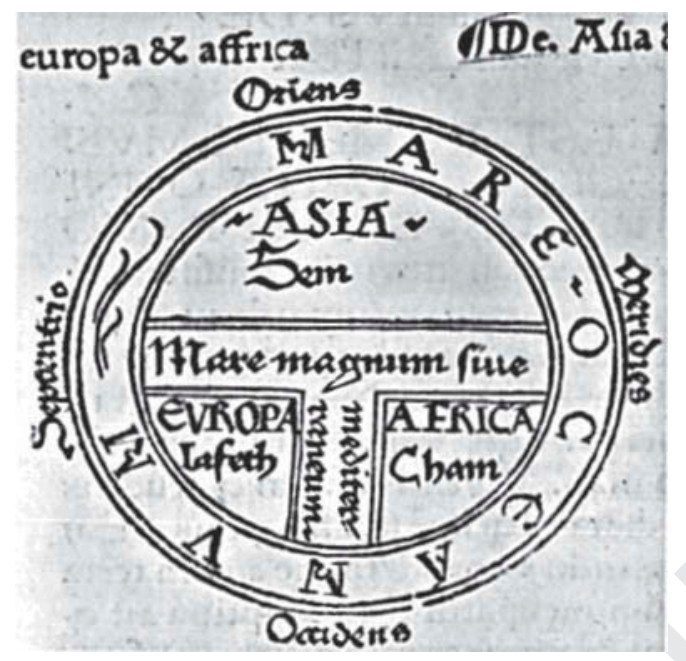

Figure 2. Isidore's original map has not survived. This is a copy from the first printed edition of the Etymologiarum. Source: http://cartographic-images.net/205_Isidore_of_Seville_T-O.html ${ }^{1}$

traditional Roman map placed the Mediterranean at the heart of the known world. The mapmakers have taken this tradition and added a layer of Christian reference. Interestingly, there is a great deal of detailed physical geography in the written text. For example, information on tides, rivers and winds is useful and usable. But such geographical knowledge does not inform the mapmaking, and the makers of the $\mathrm{T}$ and $\mathrm{O}$ map were clearly aiming to provide a view of divine order rather than any bird's eye perspective on the physical world. The encyclopaedia became a major reference work of the medieval period.

This view of the world endured for centuries, alongside a growing competence in producing accurate plans for prosaic purposes. The Mappa Mundi in Hereford cathedral is in the $\mathrm{T}$ and $\mathrm{O}$ tradition and repeats the same information, even though at the time of its creation, $1300 \mathrm{AD}$, the state of knowledge about the world meant that many of the "errors" could have been corrected (Figure 3). For example, it was then known that the Caspian Sea was enclosed. However, to criticise the map in this way is, of course, to misunderstand its purpose. The intention of the mapmaker is to give a pictorial representation of a divine plan and to situate the human race within it.

The known world is an unequivocally Christian world. The pictorial information in this part of the map is both geographical (cities and towns) and religious (reflecting Christian doctrine and biblical texts). Outside are uncharted territories full of dangerous monsters and wondrous and weird beings. There are no states, no political divisions.

Why the $\mathrm{T}$ and $\mathrm{O}$ map survives in a situation where geographical knowledge supersedes and surpasses it is interesting. Commenting on St Isidore's map, scholars have noted that "this simple design by no means reflects the breadth of knowledge and ideas that can be found in the text". 1 They ask why "this simplistic, diagrammatic plan formed the basis for one of the major design features of most subsequent 'learned' Medieval cartography and survived as a cartographic form long after more direct information made it difficult to accommodate such an artificial scheme". 2 The answer possibly lies in the symbolic aspect of the map, the role it played in providing a world view. 


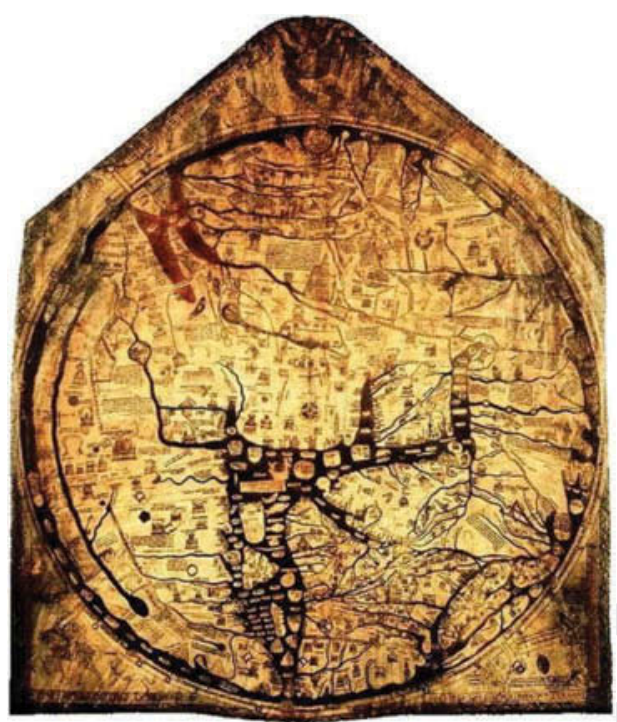

Figure 3. The Mappa Mundi. Source: http://www.herefordcathedral.org

The influence of maps would have been limited as only a minority had access to them. The European feudal world had three main classes - feudal nobility, clergy and peasantry - and only the first two of these would ever have glimpsed such a mappa mundi. The likelihood of them doing so was reasonably high since there were very large numbers of copies and versions of the $\mathrm{T}$ and $\mathrm{O}$ map in circulation. In contrast, peasants would not have seen it; they did not have access to the scriptoria where manuscripts were kept secure, often under lock and key, nor to the libraries of the nobility.

For the elites who saw it, the map would have provided a view that reflected their experiences. The centrality of religion and its homogenising influence would have seemed unexceptional. The geographical focus on biblical locations would have been natural. And although it purports to be a world map, the $\mathrm{T}$ and $\mathrm{O}$ map related everything to a Christendom that is essentially European. This perspective too would have chimed with elite experience. The clergy was European, part of hierarchies which spanned the continent and were managed from Rome or Constantinople. The feudal political system also functioned on a European scale, with ruling dynasties relying on the oaths of fealty of their subordinates and marrying and adopting to form alliances on a continent-wide scale. The warrior class lived in contradiction: unified in the sense that they saw themselves as the knights of Christendom, and fractured in a system where political power, derived from military strength and political borders, was constantly shifting. Reflecting perhaps this instability, the maps do not show political divisions. There are towns, cities and states marked, but there is no separation of kingdoms, empires and areas of influence.

When elites have such a world view, what are their prevailing language practices? All members of the clergy were, at the very least, bilingual, knowing their native language and the sacred language (to some degree). Latin, Greek and Church Slavonic were lingua francas that allowed the different parts and levels of the three Christian churches to interact on a continental scale. These were the languages of literacy and scholarship. The families of the warrior class were often multilingual because of patterns of marriage and alliance in feudal Europe. This multilingualism penetrated quite deeply into the society as the major 
figures travelled with large retinues of vassals and servants when they went to be married or to take up inheritance. Their linguistic experience was replicated among their servants. The ruling elite groups found it normal to have a language repertoire rather than be monolingual. On the other hand, peasants, the great majority of the population, were chained to the land. Their lives, identities and languages were extremely local. The map reflects this world, including the lack of clear linguistic division in geographical boundaries. Europeans did, of course, speak different languages, but the European mosaic of discrete language blocks did not yet exist. The linguistic landscape was a mixture of the messy linguistic diversity of the aristocratic world, the sacred lingua franca bilingualism of the clergy and the peasants' local practice set within dialect continua.

\section{The world view of the modern era}

Messy linguistic diversity slowly faded away in the modern era. In a number of states in the west of the continent, monarchs succeeded in curbing the power of the barons. In France, England and Spain, such rulers then set about centralising power and ruling through bureaucracies, rather than through the feudal hierarchy. The bureaucracies adopted the language of the court of the monarch in place of the chancellery Latin that had traditionally been used. The law changed, becoming the province of the monarch and the state, and moving slowly out of the control of the Church. The law courts used the language of the power centre.

In another departure from the feudal system, the practice of gifting land (and the peoples residing on them) in personal contracts of marriage and inheritance died out. Boundaries between monarchical states were negotiated in treaties and became fixed. Gradually, territory was deemed to belong to the state rather than the person of the monarch. The idea of inalienable territory which underpins the idea of the nation state gradually took hold.

Developments in the eighteenth and nineteenth centuries also contributed to the concept of the bounded nation state. For a period after the end of the feudal world, the defence of the realm was carried out by mercenary armies paid for by the monarch. After rebellion and revolution challenged the power of the monarch, the defence of the state passed to citizen armies and conscription of young men spread as a practice.

In tandem with the development of the nation state, industrialisation was also changing many parts of Europe. The urbanisation that accompanied it drew people from the country and, in the melting pots of the towns, the workers relinquished the highly individualised identities and language practices of their villages of origin. Generic education became more important for those who henceforth would work in a more conceptual way than was the case in an agricultural setting. It was the state that increasingly provides this education and in the state language (Gellner 1983).

Travel became easier, particularly within the state. When the political borders were reached, there were sometimes blocks to progress: customs duties, the new idea of passport and physical difficulties such as different track gauges for the railway.

The idea of national community began to take root. The French Revolution had promoted the ideal of the congruence of state, people and territory. Some nation builders approached the trinity from the departure point that the territory exists and needs a homogenised population; others came to it from the belief that the nation dated from time immemorial and had need of its own territorial niche. 


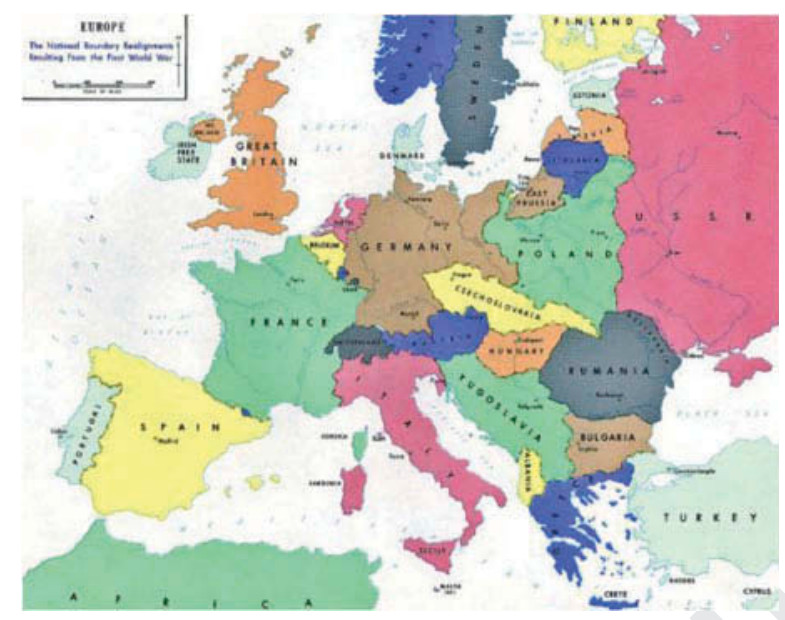

Figure 4. The European Mosaic. Source: www.europe_1919.jpg

Both theoretical positions actually resulted in a very similar policy - a desire to make the group that lives on national space a clearly identifiable, linguistically homogenous, national group (Bhabha 1990).

The maps of the era of national self-determination and nation building reflected the new political and social arrangements. The maps were a mosaic; each state was contained within its own clearly defined boundaries (Heffernan 2002) (see Figure 4).

Peoples were presented as existing in bounded space. Maps began to resemble jigsaws, with political frontiers made visible and the integrity of national spaces signalled by colour (Figure 4).

Gellner (1983, 139-140) described the differences in mapmaking in the medieval and the modern period in the following way:

Consider the history of the national principle; or consider two ethnographic maps, one drawn up before the age of nationalism, and the other after the principle of nationalism has done much of its work. The first map resembles a painting by Kokoschka. The riot of diverse points of colour is such that no clear pattern can be discerned in any detail... . Look now instead at the ethnographic and political map of an area of the modem world. It resembles not Kokoschka, but, say, Modigliani. There is very little shading; neat flat surfaces are clearly separated from each other, it is generally plain where one begins and another ends, and there is little if any ambiguity or overlap.

The tying of nation to territory has had deeply metaphysical effects; national identity became the preeminent identity for many people in the course of the twentieth century and in particular during the two world wars.

In this map, national divisions are underlined by using the national flags to differentiate the sovereign spaces (Figure 5).

Now, in parallel to these political and identity-building developments, there were changes in the way people thought about languages and the way they used them. In the course of making the modern nation state, there had been a conscious and official development and spread of the national standard language. Language planning in the service of nation building (Cooper 1989) has three aspects. Status planning decrees the use of the national language in the bounded space of the national territory. Corpus 


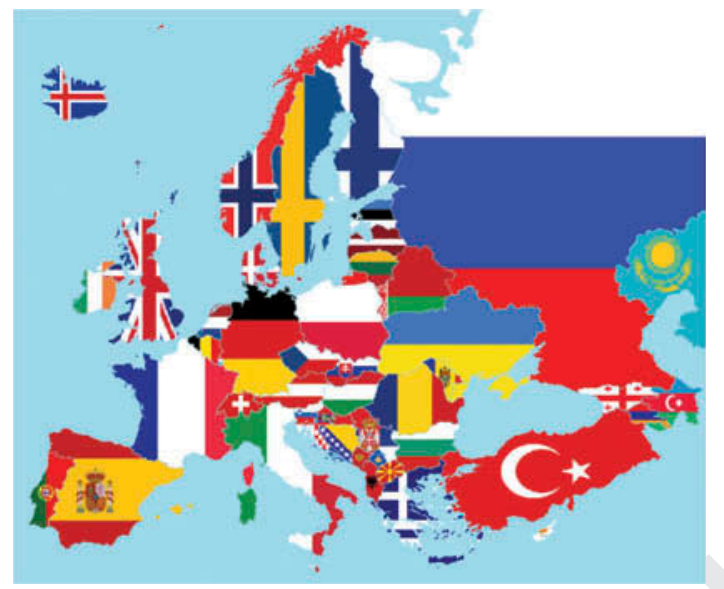

Figure 5. Europe of the nations. Source: http://historiana.eu/assets/uploads/source_-_flags_nationalism.png

planning deals with the codification and standardisation of the national language. The conventional brief is to produce a language which is discrete, distanced from other neighbouring dialects on the dialect continuum. Acquisition planning involves the spread of the national language. Here, the aim is to encourage internal convergence and establish a unitary language whose reach and currency extend to the borders of the state. To sum up, the aim of language planning is to produce a language situation where there is maximum comprehensibility within the state and maximum differentiation from speakers in neighbouring states (Milroy and Milroy 1985). The nation state system eventually divided the old dialect continua of Europe into discrete varieties in a way which mirrored the division of physical space by borders and custom posts.

And in the academy, the concept of language was also a bounded system. It can hardly be a coincidence that de Saussure's work that described language as system was produced at the end of the nineteenth and beginning of the twentieth centuries, at the height of European nation building.

The nation state system still prevails in the twenty-first century, and in some situations we continue to be moulded by it. The prevalence of the idea of bounded space continues. This resolutely national weather map comes from an Ulster TV broadcast on 17 March 2007 (Figure 6). It is in an old-fashioned format with a drawn map and symbols. The weather information concerns only the political entity; the addressees are the citizens of Northern Ireland. The Republic of Ireland apparently had no weather on 17 March 2007. This weather forecast map confirms the idea we have of bounded territory and reveals a national mindset in the people who created it. It probably reinforces awareness of the border in those who watch this weather news regularly.

Even e-technology continued the practice of giving weather information to a national audience rather than the geographical group that might be affected by the weather system. Although new technology from Google allows the user to zoom out to space and down to a locality, the old national image is still reinforced. This 2011 view of UK weather, issued by the UK Met Office and distributed by Google, maintains the bounded state view even though weather clearly crosses borders (Figure 7). The reasons for this stems in large part from the way the information is being collected by UK-based 


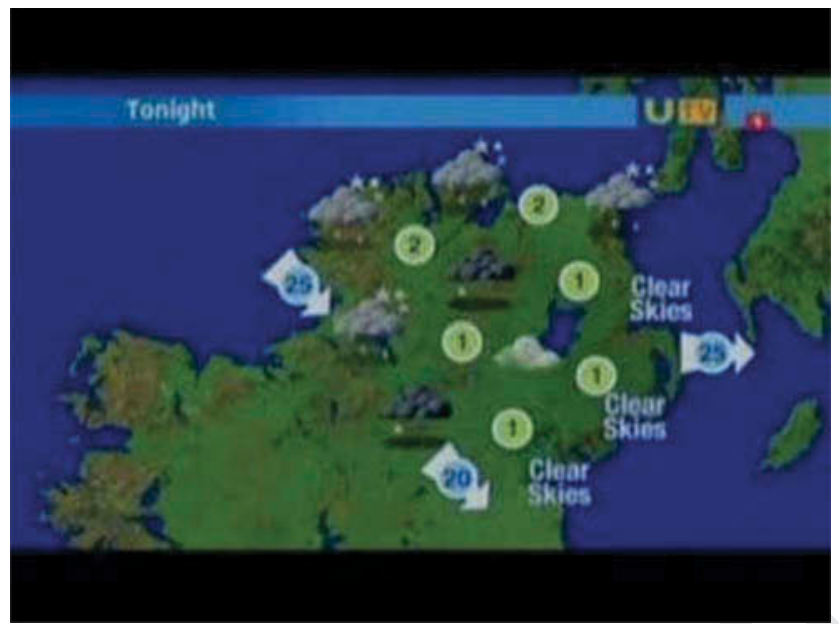

Figure 6. Ulster TV 17/03/2007

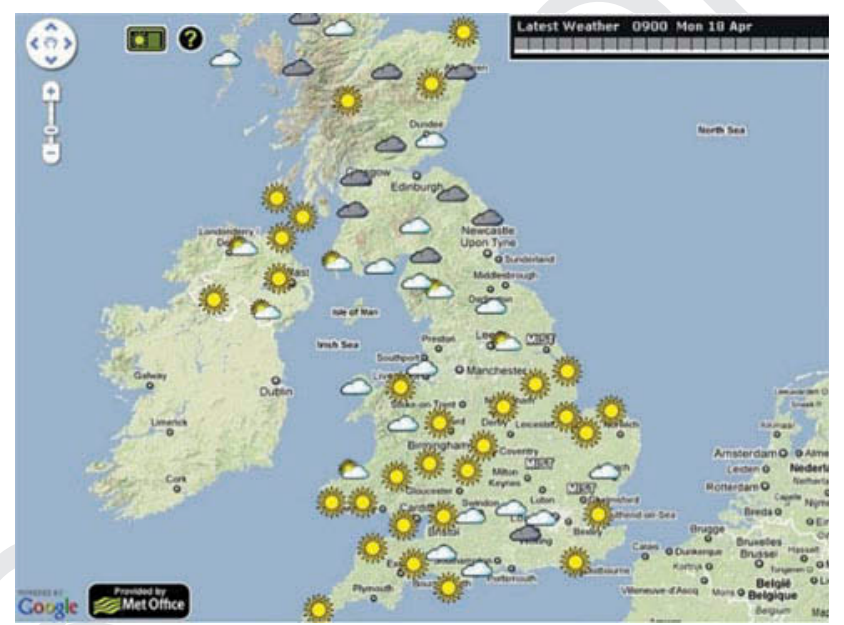

Figure 7. UK weather 10/04/2011. Source: http://www.metoffice.gov.uk/public/weather

weather stations. ${ }^{3}$ For whatever reason the practice is being continued, the image of bounded space that it reinforces probably contributes to the subliminal maintenance of a national "us" and "them" view.

The image of nation state as bounded space continues to be omnipresent in the daily 280 lives of twenty-first-century people. From fridge magnets to company logos, the symbolic representation of how we have divided up our space continues to influence our world view. And folk linguistics fits with this; languages continue to be viewed as discrete entities with vocabularies and grammars that are proper to them and to them alone. Any contravention of this idea is termed "foreign borrowing", "code switching" or indeed "error". This is particularly evident when speakers of language " $x$ " regularly borrow terms from language " $y$ ". In many cases, language policy makers attempt to halt the process. 
The concern is to protect the language from "pollution from foreign forms" rather than introduce a new word for a new process. ${ }^{4}$

\section{The world view in an increasingly post-national era}

The definition of the state as a defined territory with stable borders; a national government which is the sole law giver and law enforcer for its citizens; a domestic market usually protected by quotas and tariffs from foreign competition; a national defence force sometimes staffed through conscription and a population that identifies with the state through the complex influence of national media, a national education system, a standardised language and the elaboration of national symbols and icons still holds firm in many places in the present world. However, a closer examination of any of these characteristics will also reveal that change is taking place.

First, the territorial integrity of the nation state is routinely challenged in a way that did not happen in the past. This is particularly true in Europe, where a number of states have broken up in the past three decades and where demands for devolution and/or independence have grown (c.f. Bogdanor 1999; Guibernau 2007; Harty and Murphy 2005). Second, the nation state is no longer the sole guarantor of rights (Risse, Ropp, and Sikkink 1999; Castles and Davidson 2000; ICISS 2001). Supranational courts may be in their infancy, but they now exist and recourse to them is growing. Third, where the free market has been adopted (or imposed), much economic activity has become transnational, outside the control of the individual nation state. ${ }^{5}$ Fourth, national defence once meant having the necessary material resources and manpower to act alone to defend national interests when and wherever necessary. The events of the first decade of the twenty-first century show that some states maintain this capacity. The proliferation of nuclear capability illustrates this. But many states do not aspire to military independence and thus enter into alliances or trust in the $\mathrm{UN}^{6}$ to mobilise members' forces to counter aggression.

Fifth, and most pertinently for the present argument, the imagined society to which human beings belong is ceasing to be the nation, or at least, exclusively the nation. According to Anderson's (1983) analysis, the national media were one of the key elements in the construction of an imagined national community. This is no longer the case insofar as the national media are only one of many sources of influence and information. Those who have the language repertoires and who can afford the hardware necessary enter the flows and exchanges of the global Information Society. Powerful technologies permit real-time communication and almost limitless access to information from all parts of the world. The Internet generation forms its opinions under a much wider range of influences than did its parents or grandparents.

This argument that we are moving towards a post-national world strengthens continually. ${ }^{7}$ For each defining attribute of the nation state, one begins to find more and more examples where it no longer applies to all states or where it is weakened. This is a messy period of transition; the nation state system is far from defunct and the changes which I have described are not so well rooted that they could not be reversed by those opposed to them. However, change may be more stable when human beings start to identify with the new arrangements. There is a great deal of work on how e-technologies are encouraging new transnational flows, exchanges and networks (e.g. Held and McGrew 2007), and how these may be moulding the identity of those involved in new virtual communities. 


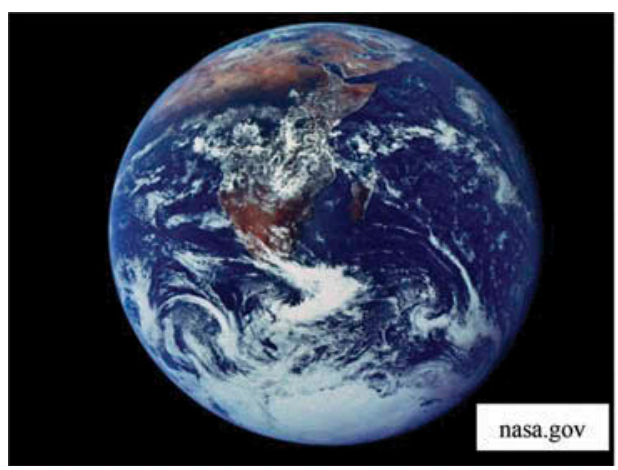

(a)

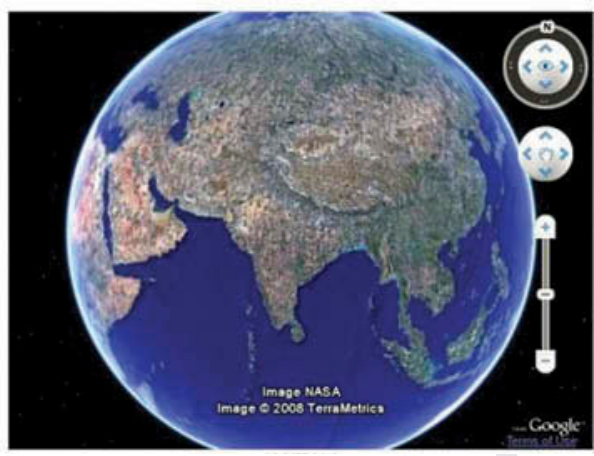

(b)

Figure 8. (a) The Blue Planet. Source: http://www.nasa.gov/. (b) The Google Map service. Source: Map data: Google, NASA, (C) 2008 Terrametrics.

In this respect, we could ask ourselves whether identities are also being affected by the world view that we get from the new maps to which we are constantly exposed. It was only in 1972 that human beings saw a picture of their planet from outer space. This famous "Blue Marble" photograph taken on 7 December 1972, as the Apollo 17 crew left the earth's orbit for the moon, is the first which allowed human beings to see the earth in its entirety (Figure 8).

The wonder of viewing ourselves from an extra-terrestrial perspective has perhaps now dissipated. The viewpoint has become banal as we use such images on a regular basis. People can log on to Google Maps/Google Earth to plan a journey to see friends or do business or to find the location of a holiday home they want to book or a specialist garage they want to use, even from a phone. However, this very banality and the fact that so many of us engage with Google Earth so frequently ${ }^{8}$ probably means that we are reformulating the mental image we have of our geographical niche. The practice of logging regularly onto a site which allows us to toggle between the world map and a precise location may ultimately have a subliminal effect on how we position ourselves. If we are constantly locating ourselves in a global context, won't this inevitably mould our identity?

Of course not all are exposed to this new imagery to the same extent. The digital divide continues to exist, and not all of humanity is involved in these new practices. However, even if we consider access to IT as the privilege of an elite, then it is a very large elite. In 2013, an estimated 2.7 billion people, just over one-third of the world's 7 billion population, were interconnected via access to the Internet and 5 billion mobile phones were reportedly in use. ${ }^{9}$

The visual imagery of this global interconnectedness is unescapable. In IT, the developing network of connections is plotted and displayed visually (Figure 9).

In the business world, particularly the world of multinational and transnational corporations, the global view is often expressed visually in planning, as here in advice about expanding into new markets (Figure 10).

This advertisement for an Indian logistics company repeats the image (Figure 11). On billboards, it forms part of the townscape and delivers the image to those who may not have access to the other sources of global imagery. It is interesting to note the centrality of the US in the image. 


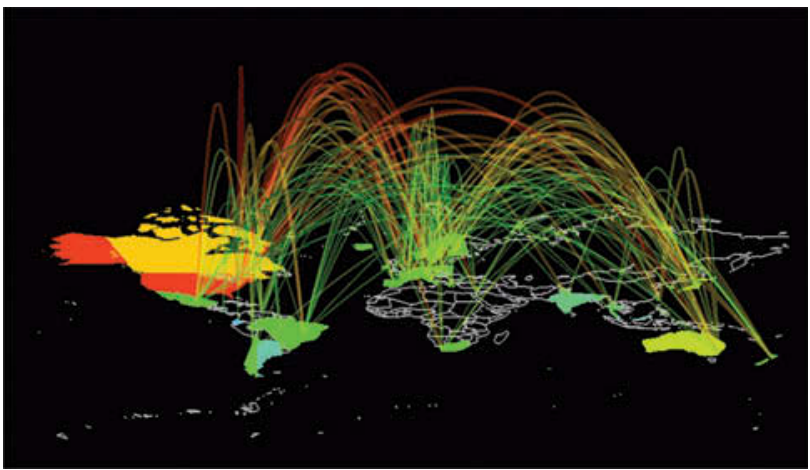

Figure 9. Global interconnectedness. Source: http://www.policy.hu/inetclass/maps/FlatWorld.gif

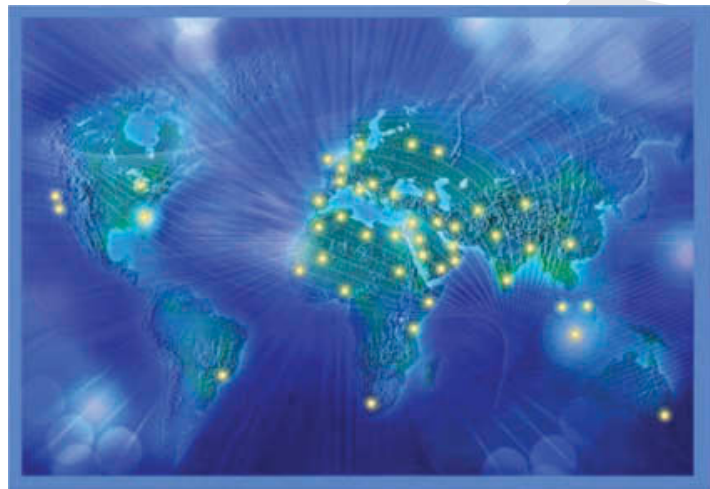

Figure 10. Planning at global level. Source: http://jeffzelaya.com/2012/01/06/take-your-seo-smoweb-agency-global-in-2012-part-1

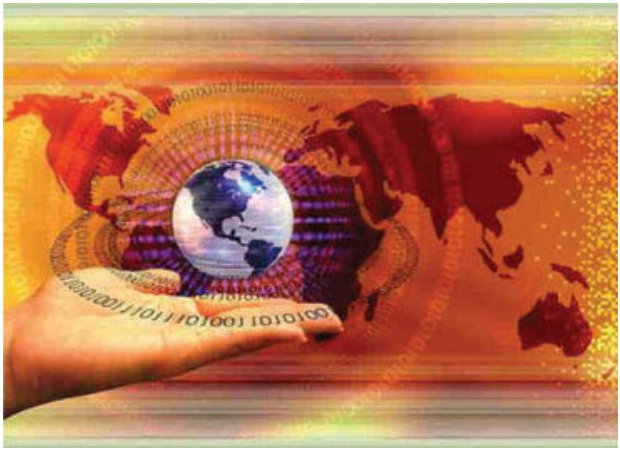

Figure 11. Global logistics. Source: GlobalLogistics_54151846_std.78131552_std.jpg 


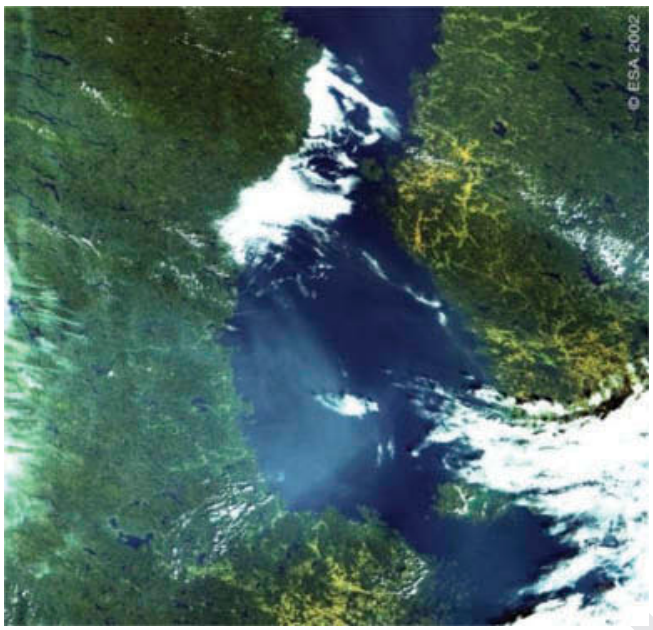

Figure 12. Satellite weather reporting. (C) ESA 2002.

New ways of showing weather forecasts introduce all those who watch television to the new imagery. Gradually, satellite weather reporting is detaching the forecast from national boundaries. The technology means that we can access real-time maps of weather systems moving across land masses and see the situation from space (see Figure 12).

This weather system sweeping in from the Atlantic crosses Sweden and Finland, and its progress can be followed in real time on the Internet. The video of the phenomenon was broadcast on Finnish TV in November 2012. In these satellite images national boundaries are not apparent except where they coincide with coastlines.

And there is a further development. e-Technology also permits us to access very precise local information about weather. As well as viewing the macro picture from the satellite, we can read the digest of information prepared for the locality in which we find ourselves (Figure 13). This is an example of glocalisation in parallel with globalisation, and the national level of analysis has become redundant. As these twin focuses replace the national perspective (wherever the provider of the information has no particular interest in promoting the national organising principle), this development may have consequences for the way we locate ourselves in physical space.

\section{Language practices}

So there are two questions to ask about language practices. The first is whether and to what extent the changing political, legal, economic and military environments exert pressure (as well as desire) on those concerned to communicate outside their local and national groups. What are the languages that such people are choosing and using in order

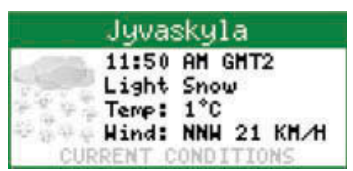


to be part of the interactions, networks and flows of information of a globalising world? The second is whether there are changes in patterns of identity which ease the move from nation state monolingualisms to the more complex language repertoires required for the flows, exchanges and networks of globalisation and whether the new maps play any kind of role in forming new patterns of identification. Do new kinds of language behaviour cooccur with new ways of conceiving who we are and where we belong?

The first thing to say in answer to the first question is that globalisation is overwhelmingly reported as promoting English. Since English is the national language of powerful states, its increasing use as a lingua franca in transnational exchange is not happening without controversy. Some, like the Dutch scholar De Swann (2001, 2013), see the spread of English as a lingua franca as ultimately useful and inevitable. He describes English as the hypercentral language in the world language constellation, and the main conduit for trans-/supra-/international communication. He argues that "if an Arab and a Chinese, or a Spaniard and a Japanese, meet they will almost certainly make themselves understood in one and the same language... English" (De Swaan 2013, 57). But this is perhaps more problematic than he admits, and a large number of scholars have disapproved the obvious benefits that English native speakers have reaped from this without effort on their part (e.g. Van Parijs 2011). Skutnabb-Kangas and Phillipson (2013, 77) have categorised the spread of English as "linguistic imperialism", with mainly negative consequences for non-native speakers. Ricento (2013) draws attention to the divisive aspects of globalisation and the spread of English.

However, these views are arguably out of date. Critics of the rise of English in the global communication sphere are tending to view the language practices through the prism of the legacy of nationalism and to conceive English in terms of the bounded system in use in the English-speaking states. However, the English used in much transnational interaction is not the variety employed as the standard/official/elite language in the UK, the US, Australia, India and Canada. There is growing evidence that many who have English in their repertoire, but who are not native speakers, use English in non-standard ways, with little concern about interference from the other languages they know and use (c.f. House 2009; Seidlhofer 2011; Jenkins 2009; Saraceni 2010; Rubdy et al. 2008). Research on Internet interaction shows how in multinational informal settings (e.g. social networks, blogging and tweeting) English is often adopted and adapted to group needs and competences with minimal respect for (or perhaps even knowledge of) native speaker norms (c.f. Leppänen, Pitkänen-Huhta, and Nikula 2011; Arnaut et al. 2011; Kytölä 2012; Blommaert et al. 2012). In this growing tolerance for hybridity, a new form of communication is developing which stands in contrast to the prescriptive and standardised language practices of the recent past. ${ }^{10}$

Moreover, there is no reason to believe that language in multilingual exchange will always be English. Already Blommaert, Leppänen, Spotti, Rampton and others have noted a complexity of dialogic interaction in the cosmopolitan cities that they have studied. The superdiversity apparent in multilingual urban settings or in transnational exchanges and flows on the Internet does include forms of English, but much else besides. Language in these contexts is created in the dialogic interaction of those who make use of it. Here, we approach the Bakhtinian idea that language "is half ours and half-someone else's.... It is not finite, it is open ... and able to reveal ever new ways to mean" (Bakhtin 1981, 345-346).

We should note too that the new political environment has not only nurtured the spread of lingua francas and language strategies for cross-cultural interaction but has also prompted the renaissance of language varieties that were eclipsed in nation building. 
Many "lesser used" or "minoritised" languages have been revitalised in recent decades accompanying political decentralisation, devolution or independence. And in this new development, we witness a similar tension between the old prescriptive model of language normalisation and the new awareness of the complexity inherent in language rights. For example, Miola (2013) contrasts the laissez faire policy of the Lombard medium Wikipedia site to the prescriptive language policy of the Piedmontese. The Lombards have embraced the linguistic flexibility afforded by the new e-technologies. The Piedmontese are attempting to promote and maintain a standard, bounded language system.

It would not be surprising if we witnessed hybridity, creativity and departure from the norm in the written form of lesser used languages. This might be expected given the statistics noted above. If over a third of humanity is accessing the Internet and if up to five people in seven have access to a mobile phone and are thus in a position to text messages, it is not surprising that language practices in lesser used languages will be informal and transgress norms routinely and significantly. It is no longer a small educated elite that is habitually reading and writing, but a wider, more heterogeneous group whose language experience will be varied. And there is some evidence that dialect speakers are accommodating along continua (Wright 2004; Miola 2013). People use their own language variety and attempt to comprehend their correspondents' variety.

Such developing practice in lingua francas and lesser used languages may well undermine the old respect for languages as bounded systems. As people use all the linguistic resources available to them to communicate, old norms will tend to be ignored and a new kind of polyphony may develop. In these settings, Bakhtin's and Wittgenstein's theories of heteroglossia are better able to describe interaction than the Saussurean or Chomskyan paradigm.

So in answer to the first question, we can say that the new global flows, exchanges, migrations and networks are clearly provoking more communication among linguistic groups. This may be in standard English, used as a lingua franca, or in non-standard English appropriated by speakers and used as a lingua franca. This may also be in one of the other languages of wider diffusion, Chinese and Spanish, where Internet use is expanding rapidly. This may be dialect speakers interacting with others on their dialect continuum and accommodating to variation. This may be creative heteroglossia among speakers of several different languages using all the linguistic resources at their disposal.

All these different practices have one thing in common; they are bottom-up "language as practice" rather than top-down "language as system". It is now common place in sociolinguistics to note that the concept of languages as "bounded units of code" (Heller 2007, 1) or "discrete bounded entities" (Makoni and Pennycook 2007, 2) has weakened as the nation state system that fostered this view has been undermined. And, without the pressure that comes where language and patriotism are confused, it becomes easier to deviate from norms (Blommaert et al. 2012; Zhang, Rubdy, and Alsagoff 2011). So we have witnessed a decrease in hyper-correction and purism and an increase in code mixing, code switching and neologism, now often seen as unproblematic (Canagarajah 2013; Dailey-O’Cain 2013).

\section{Maps, identity and language choice}

So what about the second question? Are the maps of the twenty-first century working in tandem with all the other influences that seem to be dismantling the strong sense of national boundary? Are new ways of positioning ourselves in global settings encouraging 
a weakening of national identity? Of course, the effect these new kinds of maps and images may have on identity cannot yet be fully known. But, because human beings tend to follow well-worn paths and repeat processes from the past in different ways, we might well predict that new global ways of seeing ourselves will affect our language ideologies.

From the data presented, it seems possible to claim that the map is in some kind of symbiotic relationship with language ideology and hence language use. In the medieval period, the European elite saw themselves as part of a unified whole - Christendom. Their linguistic repertoires permitted complex interaction on a continent-wide scale. In contrast, Europeans of the national period saw themselves as citizens of states with clearly defined boundaries. Monolingualism, both for the individual and for the state, became the norm.

Now many human beings regularly locate themselves on global maps. These maps have moved along the cline from construct to representation. The satellite image from space is no longer a scientific abstraction of reality but a photo image of that reality itself. These constantly updated photos are very powerful reminders of our place in our globe and may be helping build global identity. There may be some parallel to Billig's (1995) concept of banal nationalism. He argued that the daily experience of national imagery flags, icons and logos used constantly in the environment - had a massive subliminal effect on how citizens came to identify with their states. Now road maps and weather systems may be part of a set of images, practices and groupings that are constructing a new kind of supra-national "banal" identity for the part of humanity regularly touched by them.

So, in conclusion, I would like to cite what Giddens $(1984,2)$ famously said about human agency because this seems to go to the very heart of what happens in the interplay of identity and language described in the present article:

Human social activities, like some self-reproducing items in nature, are recursive. That is to say, they are not brought into being by social actors but continually recreated by them via the very means whereby they express themselves as actors.

\section{Notes}

1. Anon, http://cartographic-images.net/205 Isidore of Seville T-O.html

2. Anon, http://cartographic-images.net/205_Isidore_of_Seville_T-O.html

3. And for this reason may be a phenomenon which will disappear in the future as more information is taken from satellite sources.

4. See, for example, De Saint Robert (1986), De Broglie (1986) and Hagège (1987) on this topic. The over-riding aim is to maintain the national integrity of the language.

5. TNCs (whose turnover may be greater than the GNP of some small states) and international financial markets escape the control of national governments.

6. This is a somewhat risky position in this era of change. While it is difficult to envisage a situation where there would not be reaction to invasion, it is clear that not all contraventions of state sovereignty will receive equal treatment from a UN dominated by the present Security Council.

7. For a full discussion of this, see, for example, Held (1996) who argues that there are seven sources of political power and that five of these are now relocated partially at least to level above or below the national; Stråth and Skinner (2003) who claim that contemporary states do less than they used to do, and have more rivals that have usurped their power and Castles and Davidson (2000) who contend that globalisation has eroded the power of the nation state.

8. At the beginning of 2013 , the Google annual report noted that about a billion people use Google maps every month.

9. Mark Zuckerberg, CEO of Facebook, gave this estimated figure in a statement on 21 August 2013 on how to extend the Internet to the 4 billion plus human beings who do not yet have access (Wall Street Journal 21/08/2013). 
10. However, the bounded language system survives on the WWW alongside these new practices. For example, consumers enter a company website and are then directed (often by the symbol of national flags) to the site in their national language (Kelly-Holmes 2013). There is a growing trend on the WWW to ask volunteer translators to provide a translation from one language to another - and these languages are designated as the bounded systems linked to states (French, German and Spanish). The development of machine translation will aid the continued existence of languages in their traditional form, unless of course it draws on corpora where there are new hybridities.

\section{References}

Anderson, B. 1983. Imagined Communities: Reflections on the Origin and Spread of Nationalism. revised ed. 1991. London: Verso.

Arnaut, K., J. Blommaert, B. Rampton, and M. Spotti, eds. 2011. "Language and Superdiversities." Diversities 14 (2). Published online at: http://www.mmg.mpg.de/subsites/diversities/currentissue/language-and-superdiversities-ii/

Bakhtin, M. 1981. The Dialogic Imagination: Four Essays. Translated by C. Emerson and M. Holquist. Austin: University of Texas Press.

Bhabha, H. 1990. "Introduction: Narrating the Nation." In Nation and Narration, edited by H. Bhabha, 1-7. New York, NY: Routledge.

Billig, M. 1995. Banal Nationalism. London: Sage.

Blommaert, J., S. Leppänen, P. Pahta, and T. Räisänen. 2012. Dangerous Multilingualism: Northern Perspectives on Order, Purity and Normality. Basingstoke: Palgrave Macmillan.

Bogdanor, V. 1999. Devolution in the United Kingdom. Oxford: Oxford University Press.

Canagarajah, S. 2013. Translingual Practice: Global Englishes and Cosmopolitan Relations. London: Routledge.

Castles, S., and A. Davidson. 2000. Citizenship and Migration: Globalization and the Politics of Belonging. London: Routledge.

Cooper, R. 1989. Language Planning and Language Change. Cambridge: Cambridge University Press.

Dailey-O'Cain, J. 2013. “The Use and the Discursive Functions of English in Native-Language Online Conversations among Dutch and German Youth". Sociolinguistica 27: 146-166.

De Broglie, G. 1986. Le Français Pour Qu'il Vive. Paris: Gallimard.

De Saint Robert, P. 1986. Lettre Ouverte À Ceux Qui En Perdent Leur Français. Paris: Albin Michel.

De Swaan, A. 2013. "Language Systems." In The Handbook of Language and Globalization, edited by N. Coupland. Oxford: Blackwell.

De Swann, A. 2001. Words of the World. Cambridge: Polity.

Gellner, E. 1983. Nations and Nationalism. Ithaca, NY: Cornell University Press.

Giddens, A. 1984. The Constitution of Society: Outline of the Theory of Structuration. Berkeley: University of California Press.

Guibernau, M. 2007. The Identity of Nations. Cambridge: Polity Press.

Hagège, C. 1987. Le français et les siècles. Paris: Odile Jacob.

Harty, S., and M. Murphy. 2005. In defence of multinational citizenship. Cardiff: University of Wales Press.

Heffernan, M. 2002. "The Politics of the Map in the Early Twentieth Century." Cartography and Geographic Information Science 29 (3): 207-226. doi:10.1559/152304002782008512.

Held, D. 1996. Democracy and the Global Order. Cambridge: Polity.

Held, D., and A. McGrew, eds. 2007. Globalization Theory: Approaches and Controversies. Oxford: Polity.

Heller, M. 2007. Bilingualism: A Social Approach. Basingstoke: Palgrave Macmillan.

Hobsbawm, E. 1990. Nations and Nationalism Since 1780: Programme, Myths, Reality. Cambridge: Cambridge University Press.

Hobsbawm, E., and T. Ranger. 1983. The Invention of Tradition. Cambridge: Cambridge University 585 Press.

House, J. 2009. "English as a Lingua Franca.” Intercultural Pragmatics 6 (2): 147-170. 
International Commission on Intervention and State Sovereignty (2001). The Responsibility to Protect: Report of the International Commission on Intervention and State Sovereignty. Canada: ICISS.

Jenkins, J. 2009. "English as a Lingua Franca: Interpretations and Attitudes." World Englishes 28 (2): 200-207. doi:10.1111/j.1467-971X.2009.01582.x.

Kelly-Holmes, H. 2013. "Choose your Language!" Categorisation and Control in Cyberspace. Sociolinguistica 27: 132-145.

Kytölä, S. 2012. "Multilingual Web Discussion Forums: Theoretical, Practical and Methodological Issues." In Language Mixing and Code-Switching in Writing: Approaches to Mixed-Language Written Discourse, edited by M. Sebba, S. Mahootian, and C. Jonsson, 106-127. London: Routledge.

Lanman, J. 1981. "The Religious Symbolism of The T In T-O Maps." Journal Cartographica: The International Journal for Geographic Information and Geovisualization 18 (4): 18-22. doi:10.3138/6383-0T12-24G3-0X88.

Leppänen, S., A. Pitkänen-Huhta, and T. Nikula. 2011. National Survey on the English Language in Finland: Uses, Meanings and Attitudes. Vol. 5. Helsinki: Studies in Variation, Contacts and Change in English.

Makoni, S., and A. Pennycook. 2007. Disinventing and Reconstituting Languages. Clevedon: Multilingual Matters.

Milroy, J., and L. Milroy. 1985. Authority in Language: Investigating Language Prescription and Standardisation. London: Routledge.

Miola, E. 2013. "A Sociolinguistic Account of WikiPiedmontese and WikiLombard". Sociolinguistica 27: 116-131.

Ricento, T. 2013. "Language Policy and Globalization.” In The Handbook of Language and Globalization, edited by N. Coupland. Oxford: Blackwell.

Risse, T., S. Ropp, and K. Sikkink, eds. 1999. The Power of Human Rights: International Norms and Domestic Change. Cambridge: Cambridge University Press.

Rubdy, R., S. Mackay, L. Alsagoff, and W. Bokhorst-Heng. 2008. "Enacting English Language Ownership in the Outer Circle: A Study of Singaporean Indians' Orientations to English Norms." World Englishes 27 (1): 40-67. doi:10.1111/j.1467-971X.2008.00535.x.

Saraceni, M. 2010. The Relocation of English: Shifting Paradigms in a Global Era. Basingstoke: Palgrave Macmillan.

Seidlhofer, B. 2011. Understanding English as a Lingua Franca. Oxford: Oxford University Press.

Skutnabb-Kangas, T., and R. Phillipson. 2013. "The Global Politics of Language: Markets, Maintenance, Marginalization or Murder?" In The Handbook of Language and Globalization, edited by N. Coupland. Oxford: Blackwell.

Stråth, B., and Q. Skinner. 2003. "Introduction.” In States and Citizens: History, Theory, Prospects, edited by Q. Skinner and B. Stråth. Cambridge: Cambridge University Press.

Van Parijs, P. 2011. Linguistic Justice for Europe and for the World. Oxford: Oxford University Press.

Wall Street Journal 'Facebook's Zuckerberg Sets Forth Web Access Program'. August 21, 2013, p. B2.

Wright, S. 2004. Language Policy and Language Planning: From Nation Building to Globalisation. Basingstoke: Palgrave Macmillan.

Zhang, L., R. Rubdy, and L. Alsagoff, eds. 2011. Asian Englishes: Changing Perspectives in a Globalised World. Singapore: Pearson Prentice Hall. 